\title{
Učení v reálném světě: zkušenosti s testováním modelu pro environmentální výchovu v prrírodě ${ }^{1}$
}

\author{
Roman Kroufek $^{a}$, Jan Činčera ${ }^{b}$ \\ ${ }^{a}$ Univerzita J. E. Purkyně, Pedagogická fakulta, Katedra preprimárního \\ a primárního vzdělávání

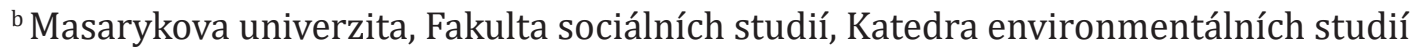

Redakci zasláno 28. 1. 2021 / upravená verze obdržena 18. 4. 2021 /

/ k uveřejnění přijato 20.4. 2021

\begin{abstract}
Abstrakt: Cílem studie je představit hlavní výsledky tř́letého ověřování modelu Real World Learning určeného pro př́pravu a realizaci programů venkovní environmentální výchovy. Výzkumu realizovaného na pěti pobytových programech se účastnili lektoři a vedoucí pracovníci center environmentální výchovy a žáci třetích až sedmých ročníků základních škol a jejich doprovázející učitelé. Pomocí kvalitativních (rozhovor, ohniskové skupiny, pozorování) i kvantitativních (dotazník) výzkumných metod byly sledovány především následující proměnné související s modelem Real World Learning: zkušenostní učení, hodnoty, empowerment, srozumitelnost programu a spokojenost s programem. Lektoři při realizaci programů inklinují k hodnotově orientovanému působení na účastníky, zaměřenému často na silné transformativní zážitky v prŕrodě. Tyto zážitky jsou účastníky pozitivně přijímány, žáci v programech oceňují prvky zkušenostního učení a zároveň netouží po přílišné autonomii směrem k ovlivňování obsahu a průběhu programu. Instrumentální přístup preferují také lektoři, podpoření $v$ tomto pohledu doprovázejícími učiteli. Ti vnímají programy především jako př́ležitost pro rozvoj sociálních kompetencí svých žáků. Z představených výsledků jsou vytvořena doporučení pro realizaci venkovních programů environmentální výchovy.
\end{abstract}

Klíčová slova: venkovní environmentální výchova, zkušenostní učení, hodnoty, empowerment

Realizace environmentální výchovy prostřednictvím několikadenních venkovních programů (outdoor environmental education program) je často vnímána jako vhodná cesta pro posilování proenvironmentálních postojů, hodnot, senzitivity i chování (Otto \& Pensini, 2017; Palmer, 1993; Palmberg

1 Př́íspěvek je jedním z výstupů projektu Promoting Behavioral and Value Change through Outdoor Environmental Education, podpořeného pod číslem GA18-15374S Grantovou agenturou České republiky. 
\& Kuru, 2000). Jako účinné prostředky pro dosažení těchto cílů jsou ve venkovních programech vnímány především silné a zapamatováníhodné zážitky z prŕrody (Chawla, 1999).

To, zda bude program v plnění svých cílů úspěšný, je ovlivněno řadou faktorů. Silný vliv na vnímání zážitků a zkušeností nabytých v programu má způsob, jakým dospělí (lektoři, doprovázející učitelé) tyto zážitky rámují (Bateson, 1972), a tedy komunikují směrem k účastníkủm (Carson, 2017). Kromě vhodné komunikace je klíčový také celkový přístup lektora k účastníkům (O'Hare et al., 2020). Úspěšné programy jsou často propojeny se školním kurikulem sérií aktivit probíhajících před a po programu přímo ve škole (Dettman-Easler \& Pease, 1999; Menzies et al., 2017). Jako vhodné se pak jeví zapojení doprovázejícího učitele přímo do plánování programu (Kendall \& Rodger, 2015). V neposlední řadě je často zmiňovaným faktorem empowerment, tedy možnost účastníků aktivně se podílet na ovlivňování podoby aktivit programu (Povilaitis et al., 2019).

Evaluaci venkovních programů environmentální výchovy se věnuje celá řada studií dokládajících pozitivní dopady na výše jmenované proměnné (např. Ardoin et al., 2015a, 2015b; Bogner, 2002; Činčera et al., 2015; DettmannEasler \& Pease, 2010; Jirasek et al., 2017; Samperiz \& Herrero, 2018). Víme tak poměrně dobře, zda je nějaký program efektivní co do konkrétních výstupů, ale chybí analýzy dílčích edukačních strategií a přístupů a jejich vnímání samotnými účastníky. Řada programů také postrádá dostatečné teoretické zázemí ospravedlňující výběr těchto strategií (Hungerford, 2005).

$\mathrm{V}$ rámci hledání cesty, jak tento rozkol mezi teorií a praxí napravit, byla v roce 2013 vytvořena sít aktérů venkovní a environmentální edukace, která se ze šesti zakládajících států (Velká Británie, Německo, Itálie, Česká republika, Mad’arsko a Slovinsko) rozrostla na více než 30 partnerů. Hlavním výstupem jejich spolupráce byl po dvou letech diskusí Real World Learning (RWL) Model (RWL, 2020). Model je graficky znázorněn do podoby ruky, jejíž jednotlivé prsty představují klíčové komponenty modelu: hodnoty, porozumění, přenositelnost, zkušenosti a rozvoj kompetencí (RWL, 2020). Model zdůrazňuje tři klíčové hodnoty: (1) respekt k přírodě a starost o stav planety, (2) rovné př́iležitosti pro všechny lidi a (3) respekt k budoucím generacím (RWL, 2020). Podle modelu by se kvalitní programy měly soustředit na výuku vybraných ekologických principů a dále by měly podporovat rozvoj kompetencí žáků poskytováním příležitostí k řízení vlastního učení, pomoci žákům propojovat vyučovaná témata s jejich vlastním životem, ale i s událostmi jinde ve světě, 
vycházet z principů zkušenostního učení a komunikovat hodnoty univerzalismu a benevolence. Programy jako celek by současně měly komunikovat srozumitelné hlavní sdělení související s udržitelným životem.

V textu představujeme výsledky tř́letého výzkumu pobytových programů environmentální výchovy, nahlížených prismatem modelu Real World Learning. V letech 2018-2020 zpracovali autoři v tomto kontextu několik dílčích studií (Činčera et al., 2020a, 2020b, 2020c, 2020d) ${ }^{2}$ a monografii (Činčera et al., 2021). Hlavním cílem těchto textů bylo: (1) zjistit, jak významní domácí experti na oblast outdoorové environmentální výchovy vnímají význam programů a předpoklady jejich účinnosti, (2) analyzovat, jak lektoři a vedoucí center environmentální výchovy hodnotí význam jednotlivých kategorií modelu, (3) vyhodnotit, jaký význam mají pobytové programy environmentální výchovy pro učitelé základních škol a pro žáky, kteří se jich účastní, (4) vyhodnotit, do jaké míry jsou sledované kategorie modelu ve vybraných pobytových programech využívány, a (5) analyzovat, zda míra implementace těchto kategorií souvisí s formováním environmentálních hodnot a chování žáků.

V tomto textu podáme shrnující odpovědi na otázky korespondující s dílčími studiemi (viz výše):

- Jakým způsobem lektoři nahlíží zkušenostní učení?

- Jaké hodnoty jsou v rámci programů předávány a jakým způsobem?

- Jak je lektory a žáky vnímána žákovská možnost participace na programu (empowerment)?

- Jaké aspekty ovlivňují srozumitelnost programu pro jeho účastníky?

- Co ovlivňuje spokojenost účastníků s programem venkovní environmentální výchovy?

\section{Metodologie}

Pro zodpovězení výše uvedených otázek byla získána data prostřednictvím čtyř ohniskových skupin s 22 experty na oblast environmentálního vzdělávání, 17 rozhovorů s lektory a vedoucími pracovníky center environmentální

2 Další texty, věnované spokojenosti studentů s programy, vztahu mezi charakteristikami programu a environmentálními hodnotami žáků a pohledu učitelů na programy jsou aktuálně v recenzním řízení. 
výchovy, 17 rozhovorů s učiteli na základních školách, osmi ohniskových skupin s celkem 68 žáky základních škol účastnících se zvolených programů, 336 dotazníků zadaných žákům před programem, krátce po něm a následně znovu s delším odstupem. Dvěma nezávislými pozorovateli bylo také pozorováno pět vybraných pobytových programů environmentální výchovy. Žáci pocházeli ze 3. až 7. ročníků základní školy. Zastoupení dívek a chlapců bylo vyrovnané, průměrný věk činil 10,47 roku.

Při přímém pozorování se výzkumníci zaměřovali na sledování toho, jak jsou programy rámovány, jaké hodnoty podporují (sledované jádrové hodnoty: univerzalismus, vlastní svoboda, benevolence, zážitky, hédonismus, konformita, tradicionalismus, výkonová orientace, síla, bezpečnost), jak je v nich podporována přenositelnost (časový a prostorový rámec transferability programu) a jak program pomáhá podporovat přesvědčení účastníků o vlastním vlivu (locus of control).

Ohniskové skupiny s žáky proběhly dva týdny po realizaci programu a byly zaměřené na interpretaci účastnické zkušenosti s programem a jeho aktivitami. Ve stejném čase byl žákům administrován dotazník zaměřený na následující aspekty programů: rámování a srozumitelnost, přenositelnost do běžného života, zkušenostní učení, empowerment a konečně spokojenost s programem.

Rozhovory s doprovázejícími učiteli byly zaměřené na jejich očekávání spojená s programem a jeho slabé a silné stránky. Konkrétně byly opět diskutovány klíčové oblasti spojené s modelem RWL (rámování a srozumitelnost, hodnoty, přenositelnost, zkušenost a empowerment). Tyto oblasti byly reflektovány také při rozhovorech s lektory programů.

Ohniskové skupiny s experty na oblast environmentálního vzdělávání spočívaly v diskusi nad rolí zkušenosti v programech venkovní environmentální výchovy, nad smyslem, efektivitou, kvalitou a limity těchto programů a nad učebním procesem, který při realizaci programů probíhá. Konkrétní podobu dotazníků, pozorovacích archů i struktury rozhovorů podávají Činčera a kol. (2021).

Získaná data byla zpracována standardními postupy. Kvalitativní data byla vyhodnocena pomocí otevřeného kódování (Saldana, 2015), kvantitativní pak zpracována pomocí induktivních statistických metod. 


\subsection{Programy}

Každý z pěti sledovaných pobytových programů byl realizován jiným střediskem environmentální výchovy. Nabídka programů a jejich výběr školami probíhal standardně. Školy si program vybraly z nabídky centra dle své preference a vhodnosti programu pro konkrétní skupinu žáků. Pro pracovníky center environmentální výchovy nepředstavuje přítomnost výzkumníků výraznou zátěž, na centrech často probíhají evaluace programů. Pro zajištění anonymity byly programy označeny barevnými kódy. Konkrétní představu o hlavních deklarovaných cílových oblastech, délce a prostředí, kde se programy odehrávaly, si lze učinit z tabulky 1 . Podrobnější popis programů lze nalézt u Činčery a kol. (2021).

\section{Tabulka 1}

Přehled analyzovaných programů

\begin{tabular}{|c|c|c|c|}
\hline Program & Prostředí & Cíle & Délka (dny) \\
\hline Modrý & hory & vztah k místu & 3 \\
\hline Zelený & lužní les & $\begin{array}{l}\text { ekologické principy } \\
\text { environmentální hodnoty }\end{array}$ & 5 \\
\hline Oranžový & pískovcové skály & $\begin{array}{l}\text { ekologické principy } \\
\text { environmentální hodnoty a chování }\end{array}$ & 3 \\
\hline Žlutý & venkov & $\begin{array}{l}\text { outdoorové dovednosti } \\
\text { vztah k př́rodě }\end{array}$ & 5 \\
\hline Bílý & krasová oblast & $\begin{array}{l}\text { outdoorové dovednosti } \\
\text { vztah k př́rodě }\end{array}$ & 5 \\
\hline
\end{tabular}

\section{Výsledky a diskuse}

V následujícím přehledu výsledků budou představeny aspekty venkovních programů environmentální výchovy, které byly sledovány v průběhu výzkumu. Struktura kapitoly odpovídá definovaným výzkumným otázkám. Pro zachování plynulosti textu byl diskusní aspekt zahrnut př́mo do konkrétních výsledků.

\subsection{Zkušenostní učení}

Všichni lektoři jsou přesvědčeni, že zkušenostní učení je významnou součástí programů venkovní environmentální výchovy. Poměrně výrazně se však 
liší jejich koncepty zkušenostního učení a také jeho vlastní realizace. V rámci analýzy byly u lektorů identifikovány tři teoretické rámce nahlížení na zkušenostní učení.

Lektoři vycházející z teorie autentického učení preferují pouze částečně připravené zážitky, které účastníkủm přinese autentický kontakt s př́rodou. Nesměřují ale k výrazným, transformativním zážitkům, spíše usilují o zisk „běžné“ zkušenosti. Reflexi takto získaných zkušeností zařazují lektoři nepravidelně, pouze $\mathrm{v}$ případě, kdy „je to potřeba“. V rámci takové reflexe pak vnímají svou roli pouze jako facilitační.

Druhá skupina lektorů vnímá zkušenostní učení jako doplněk, který umožňuje získávání vědomostí a dovedností v atraktivním přírodním prostředí, což vede $\mathrm{k}$ hlubšímu ukotvení nově získaného. Prožitá zkušenost by podle nich měla být komfortní a nepř́liš silná. Tito lektoři zároveň upřednostňují instrumentální přístup s nízkým vlivem studentů na realizovaný program. Reflexivní momenty jsou pravidelné, plánované a jsou vnímané jako významná část procesu učení.

Nejčastější teorie, ke které se lektoři vztahovali, byla teorie transformativních zážitků. Učení podle lektorů probíhá vystavováním účastníků silným, neobyčejným a emocemi nabitým zážitkům. Často se jedná o předem pečlivě připravený sled událostí (noční stezka, osamělý pobyt v př́rodě...). Síla zážitku je pak jeho kvalitou, protože pomáhá účastníkům vystoupit mimo jejich komfortní zónu (Priest \& Gass, 2005). Čím silnější je prožitá zkušenost, tím více transformativní potenciál má a může podle lektorů trvale změnit postoje či kompetence účastníků. Po takovém zážitku pak následuje reflexe, která je vedena lektorem. Ten účastníkům vysvětluje smysl zážitku, a nabízí tak jeho specifickou interpretaci.

Možnost zakusit silné zážitky v rámci zkušenostního učení byla také nejčastějším kladem, který programům připisovali doprovázející učitelé. Ti dále vyzdvihovali rozvoj sociálních kompetencí účastníků; naopak zvyšování environmentálních kompetencí a hodnot nepokládali za tolik významné nebo je dokonce zpochybňovali.

\subsection{Hodnoty}

Při analýze toho, jakým způsobem jsou ve venkovních environmentálních programech předávány hodnoty a jaké tyto hodnoty jsou, byl identifikován 
rozdíl mezi pohledem lektorů a reálnou praxí. Ve všech sledovaných programech byl zjištěn normativní př́istup založený na vštěpování specifických, převážně universalistických (rovnost, jednota se světem, ochrana životního prostředí, vnitřní harmonie, moudrost; Schwartz, 1994) hodnot bez jejich kritické analýzy. Na základě tohoto sledování můžeme venkovní environmentální výchovu označit jako hodnotově orientovanou (Scott \& Oulton, 2006), zakořeněnou ve specifických hodnotách, které jsou předávány v rámci její praktické realizace. Ačkoli je hodnotově orientované pojetí některými odborníky podrobováno kritice (Hug, 2005) upozorňující na riziko možné indoktrinace, vzdělávání nelze zřejmě nikdy vnímat jako hodnotově zcela neutrální (Sutrop, 2015).

Myšlenku hodnotově neutrální realizace programů environmentální výchovy ostatně podpořili pouze dva z lektorů. Při vlastní realizaci programu, kdy byly účastníkům představovány vybrané environmentální koncepty, ale oba zastávali konkrétní hodnoty (např. ochrana a ocenění přírody).

Několik lektorů zastávalo pluralitní přístup pro komunikaci hodnot v rámci programu. Vycházeli z přesvědčení, že účastníkům mají být představeny různé hodnotové orientace související s tématem programu (např. les jako zdroj materiálu i radosti). Při přímém pozorování byla u všech programů identifikována komunikace pestrého spektra hodnot. $V$ některých př́padech lektoři komunikovali protichůdné hodnoty, např́klad zdůrazňovali hodnotu kooperace („toto není soutěž“) a zároveň výsledky účastníků bodovali.

Většina lektorů se přikláněla k normativnímu přístupu. Programy by dle nich měly komunikovat konkrétní hodnoty ve shodě se svými cíli. Někteří lektoři deklarovali, že účastníky přímo vedou k hodnotám, které jsou univerzálně akceptované (ochrana přírody aj.). $V$ žádném z programů však nebyly předávané hodnoty explicitně reflektovány a účastníkům nebylo umožněno tyto hodnoty analyzovat z jejich vlastního pohledu.

\subsection{Empowerment}

Významnou otázkou je žákovská participace na programu. Určitá hodnota žákovské autonomie a kontroly nad programovými aktivitami je většinou vnímána jako pozitivní a ze strany žáků oceňovaná (Mullenbach et al., 2019; Stern et al., 2014). Námi sledovaní účastníci ale převážně upřednostňovali instrumentální pojetí programů s jasně definovanými aktivitami. Kontrolu chtěli pouze nad svým volným časem, který chtěli trávit nemoderovanou 
zábavou s vrstevníky, do vlastních programů zasahovat nepotřebovali. Tento fakt může souviset také s délkou programů a věkovým složením účastníků, kdy především mladší účastníci postrádají potřebné dovednosti pro relevantní participaci na tvorbě programu.

Lektoři a učitelé také zpochybňovali schopnost žáků participovat na rozhodování spojeném s programem. Instrumentální pojetí programu podle nich eliminuje možné konflikty mezi účastníky, je efektivnější cestou k dosahování cílů programu a zvyšuje celkovou spokojenost účastníků. Volnost účastníkům poskytovali $\mathrm{v}$ otázce vypořádání se $\mathrm{s}$ předpřipravenými aktivitami, ale neumožnili jim výběr z těchto aktivit. Což koneckonců účastníkům vyhovovalo. Instrumentálnost programu tak nelze jednoznačně vnímat jako jeho nedostatek, byt' je většinou doporučována vysoká míra autonomie a participace účastníků (Kendall \& Rodger, 2015; Menzies et al., 2017).

Nejednoznačné je téma opouštění komfortní zóny účastníků. Zatímco adrenalinová zábava ve formě nočních her či raftingu je vnímána pozitivně, nepříznivé počasí, dlouhé pochody, neobvyklé jídlo či absence Wi-Fi negativně ovlivňovaly zkušenost účastníků s programem. Negativní vnímání obdobného diskomfortu zjistili také další autoři (Talebpour et al., 2020; West, 2015). Je tedy patrný jasný rozdíl mezi očekávaným strachem a nepohodlím pramenícím $\mathrm{z}$ dobrodružných aktivit a nepohodlím zakoušeným např. ve volném čase účastníků.

\subsection{Srozumitelnost}

Zajímavým tématem jsou komunikační rámce, které tvůrci a lektoři využívají. $V$ rámci analýzy byly $\mathrm{v}$ některých případech identifikovány diskrepance mezi tím, co aktivity programu směrem k účastníkủm komunikují, a vlastním záměrem tvůrců programu. Tento nesoulad se objevoval především v momentech, kdy měly programy komunikovat specifická poselství, nikoli pouze obecně zvyšovat proenvironmentální postoje a hodnoty.

Každý z programů byl komunikován jednak srozumitelným „vnějším“ rámcem (moudrost indiánů, návrat života na zničený vulkanický ostrov...), který byl někdy doprovázen alternativním rámováním (místo kde žijeme...). Tyto „vnější“ rámce byly většinou komunikovány s účastníky explicitně za pomoci vizuálií, písní či rituálů; snahou bylo navodit pocit tajemství a mystéria, což mohlo snižovat autenticitu programu, nicméně jde o př́stup, který má v programech environmentální výchovy dlouhou tradici (Van Matre, 1990). 
„Vnitřní" rámování programů (vztah k místu, odpovědný život, ocenění přírody...) bylo spíše implicitní a ne všichni lektoři byli schopni tyto vnitřní komunikační rámce jasně definovat, případně nebyla tato definice sdílena lektory totožného programu. Zajímavé je, že u většiny programů jejich účastníci definovali vnitřní rámec alternativně, většinou jako potřebu chránit př́irodu, což bylo téma, které lektoři záměrně i nezáměrně komunikovali napříč programy.

Možná nesrozumitelnost programu pramení také z rozdílného vnímání jeho cílů. Zatímco tvůrci a lektoři vidí cíle v rozvoji proenvironmentálních hodnot, vědomí a chování, doprovázející učitelé očekávají především zlepšení sociální soudržnosti skupiny a rozvoj pozitivních vztahů mezi žáky. Ti se těší na zábavu, dobrodružství a společný volný čas s vrstevníky. Komunikace uvnitř programu tak může být pro účastníky matoucí (Cachelin et al. 2010; Cachelin et al. 2011).

\subsection{Spokojenost}

Spokojenost žáků s absolvovanými programy byla vysoká $(\mathrm{M}=4,26$, $\mathrm{SD}=1,08)$, v rámci regresního modelu ji ze $48 \%(\mathrm{R} 2=0,48, \mathrm{~F}=62,43$, $\mathrm{p}<0,0001)$ vysvětlují proměnné jasnost programu $(\beta=0,32)$ a modelová role lektora $(ß=0,35)$. Účastníci vyjadřovali přání strávit na programech více dní. Věděli, že se učí, ale oceňovali nejrůznější aspekty realizovaného zkušenostního učení jako venkovní výuku, hraní her a předávání smysluplného obsahu. Upozorňovali na velký rozdíl mezi učením se v rámci programu a školní výukou, kterou v tomto kontextu hodnotili spíše negativně. To souvisí také s nízkým zapojením doprovázejících učitelů, kteří by jinak měli sloužit jako aktéři přenositelnosti výstupů programu do školního prostředí (Stern et al., 2008, 2014). Někteří účastníci vnímali negativně časovou náročnost badatelských aktivit či vyjadřovali odpor při aktivitách s živočichy.

Přímá interakce s přírodou byla ale také nejčastěji označována jako nejsilnější zážitek, který si účastníci odvážejí. Většina těchto zážitků měla pozitivní nádech spojený s fascinací a obdivováním př́rody.

Žáky oceňovaná erudovanost lektorů, jejich schopnost motivovat a vysvětlit smysl jednotlivých aktivit, je u programů environmentální výchovy dokládána opakovaně (James \& Bixler, 2008; Mullenbach et al., 2019; Sibthorp et al., 2020; Stern et al., 2014). Účastníci mnohdy vyžadovali pozornost lektorů po celou dobu trvání programu a nelibě nesli momenty, kdy se jim lektoři 
nemohli věnovat. Je možné, že v lektorovi viděli „bezpečný př́ístav“ v pro ně neznámém prostředí. Role lektorů byla zásadní také pro pozitivní přijetí celodenních túr v př́rodě. Pokud se lektoři účastníkům delší dobu nevěnovali, zažívali tito pocit nudy.

Spokojenost s programem byla také ovlivněna sociálními interakcemi uvnitř skupiny účastníků, což je téma, které bývá v evaluacích programů sledováno dosud spíše okrajově (Cheeseman \& Wright, 2019; James \& Bixler, 2008). Neschopnost spolupracovat na aktivitě či rivalita mezi žáky vedla občas k nespokojenosti s programem jako takovým. Na druhou stranu účastníci oceňovali možnost trávit s vrstevníky volný čas, někteří tyto momenty označovali jako nejlepší části programu.

\section{Doporučení pro realizaci venkovních programů environmentální výchovy}

Předkládaná zjištění vedou k vytvoření série doporučení, která mohou přispět ke zvýšení kvality venkovních programů environmentální výchovy.

Pro spokojenost žáků je nejdůležitější jasnost a srozumitelnost programu, kdy potřebují pochopit význam jednotlivých aktivit.

Tvůrci programu a lektoři by se společně s učiteli měli snažit stírat hranici mezi školní výukou a programem, kterou žáci vnímají velmi ostře. V kontextu silných zážitků z programu pak může tento stav vést ke slepé kritice školních aktivit. Zmiňované stírání hranice vyžaduje hlubší zapojení vyučujícího formou před a post programových aktivit ve škole či př́mé participace na tvorbě programu a jeho cílů.

Jako významná se jeví práce se skupinovou dynamikou, kdy sociální vztahy mezi účastníky mohou v pozitivním př́ípadě zvýšit celkovou spokojenost $\mathrm{s}$ programem, $\mathrm{v}$ tom negativním pak zamýšlené výsledky programu snížit. Sociální interakci v rámci skupiny se samozřejmě nelze vyhnout, a i proto by s ní měli tvůrci a lektoři aktivně pracovat. Pozitivní změny v sociálních vztazích očekávají žáci i doprovázející učitelé a je-li tento aspekt ze strany lektorů ponechán bez povšimnutí, snižuje se tím celková spokojenost s programem.

Dalším z výrazných aspektů vedoucích ke spokojenosti s programem jsou silné zážitky odehrávající se v př́rodě. $\mathrm{V}$ tomto směru lze doporučit kombinovat připravené zážitky (noční hry, průzkum jeskyní) s vhodným využitím 
spontánních, autentických zážitků (neplánované setkání s živočichem, silný déšt' na výpravě). Pro interpretaci zážitků účastníky se zdá být klíčový způsob, jakým jej lektor rámuje a komunikuje. Významné je to např́́klad u výprav na delší vzdálenosti, kdy do hry vstupuje také aspekt fyzické výdrže. Dủležitý je následný rozbor zážitku a získané zkušenosti lektory, učiteli i žáky, a to při poskytnutí dostatečného prostoru poslední jmenované skupině.

Pro vlastní tvorbu a řízení programů se jako nanejvýš vhodné ukazuje zapojení lektorů do tvorby programů. Částečně se tak lze vyhnout nesrovnalostem v komunikačních rámcích programů a ve způsobech, jakými je v programech realizováno zkušenostní učení. $V$ tomto směru je klíčová také vzájemná komunikace mezi lektory odpovědnými za totožný program. Ta může předcházet odlišné implementaci programu.

Specifickou otázkou je další vzdělávání lektorů, které by vedlo k ujasnění teoretických konceptů souvisejících s učením a zároveň mohlo rozšírit kompetence pro reflexi vlastní lektorské práce.

V rámci programu nezapomínejme, že účastníci jsou dětmi, které sice dokáží ocenit krásu přírody, ale stále touží po dobrodružství a zábavě. A to jim musíme nabídnout.

\section{Literatura}

Ardoin, N. M., Biedenweg, K., \& O'Connor, K. (2015a). Evaluation in residential environmental education: An applied literature review of intermediary outcomes. Applied Environmental Education \& Communication, 14(1), 43-56.

Ardoin, N. M., DiGiano, M., O'Connor, K., \& Holthuis, N. (2015b). Using online narratives to explore participant experiences in a residential environmental education program. Children's Geographies, 14(3), 263-281.

Bateson, G. (1972). Steps to an ecology of mind. University of Chicago Press.

Bogner, F. X. (2002). The influence of a residential outdoor education programme to pupil's environmental perception. European Journal of Psychology of Education, 17(1), 19-34.

Carson, R. (2017). The sense of wonder. Harper Perennial.

Cachelin, A., Norvell, R., \& Darling, A. (2010). Language fouls in teaching ecology: Why traditional metaphors undermine conservation literacy. Conservation Biology, 24, 669-674.

Cachelin, A., Rose, J., Dustin, D., \& Shooter, W. (2011). Sustainability in outdoor education: Rethinking root metaphor. The Journal of Sustainability Education, 2, 22-44.

Činčera, J., Johnson, B., \& Kovacikova, S. (2015). Evaluation of a place-based environmental education program: From here to there. Applied Environmental Education and Communication, 14(3), 178-186.

Činčera, J., Johnson, B., \& Kroufek, R. (2020a). Outdoor environmental education programme leaders' theories of experiential learning. Cambridge Journal of Education, online first. 
Činčera, J., Johnson, B., Kroufek, R., Kolenatý, M., \& Šimonová, P. (2020b). Frames in outdoor environmental education programs: What we communicate and why we think it matters. Sustainablity, 12, 4451.

Činčera, J., Johnson, B., Kroufek, R., \& Šimonová, P. (2020c). Values education in outdoor environmental education programs from the perspective of practicioners. Sustainability, 12, 4700 .

Činčera, J., Šimonová, P., Kroufek, R., \& Johnson, B. (2020d). Empowerment in outdoor environmental education: Who shapes the programs? Environmental Education Research, 26(12), 1690-1706.

Činčera, J., Johnson, B., Kroufek, R., Kolenatý, M., Šimonová, P., \& Zálešák, J. (2021). Real world learning in outdoor environmental education programs. Munipress.

Dettmann-Easler, D., \& Pease, J. L. (1999). Evaluating the effectiveness of residential environmental education programs in fostering positive attitudes toward wildlife. The Journal of Environmental Education, 31(1), 33-39.

Hug, J. (2005). Two hats. In R. H. Hungerford, W. J. Bluhm, T. L. Volk, \& J. M. Ramsey (Eds.), Essential readings in environmental education (s. 47). Stipes.

Hungerford, H. R. (2005). The myths of environmental education - revisited. In R. H. Hungerford, W. J. Bluhm, T. L. Volk, \& J. M. Ramsey (Eds.), Essential readings in environmental Education (s. 49-56). Stipes.

Chawla, L. (1999). Life paths into effective environmental education. The Journal of Environmental Education, 31(1), 15-26.

Cheeseman, A., \& Wright, T. (2019). Examining environmental learning experiences at an earth education summer camp. Environmental Education Research, 25(3), 375-387.

James, J. J., \& Bixler, R. D. (2008). Children's role in meaning making through their participation in an environmental education program. The Journal of Environmental Education, 39(4), 44-59.

Jirásek, I., Veselský, P., \& Poslt, J. (2017). Winter outdoor trekking: Spiritual aspects of environmental education. Environmental Education Research, 23(1), 1-22.

Kendall, S., \& Rodger, J. (2015). Evaluation oflearning away: Final report. Paul Hamlyn Foundation.

Menzies, L., Bowen-Viner, K., \& Shaw, B. (2017). Learning away: The state of school residentials in England 2017. LKM. http://www.learningaway.co.uk

Mullenbach, L. E., Andrejewski, R. G., \& Mowen, A. J. (2019). Connecting children to nature through residential outdoor environmental education. Environmental Education Research, 25(3), 365-374.

O’Hare, A., Powell, R. B., Stern, M. J., \& Bowers, E. P. (2020). Influence of educator's emotional support behaviors on environmental education student outcomes. Environmental Education Research, 1-22.

Otto, S., \& Pensini, P. (2017). Nature-based environmental education of children: Environmental knowledge and connectedness to nature, together, are related to ecological behaviour. Global Environmental Change, 47, 88-94.

Palmberg, I. E., \& Kuru, J. (2000). Outdoor activities as a basis for environmental responsibility. The Journal of Environmental Education, 31(4), 32-36.

Palmer, J. A. (1993). Development of concern for the environment and formative experiences of educators. Journal of Environmental Education, 24, 26-30. 
Povilaitis, V., Riley, M., DeLange, R., Verkouw, A. J., Macklin, K., \& Hodge, C. J. (2019). Instructor impacts on outdoor education participant outcomes. A systematic review. Journal of Outdoor Recreation, Education and Leadership, 11(3), 222-238.

Priest, S., \& Gass, M. A. (2005). Effective leadership in adventure programming. Human Kinetics. RWL (2020). Real World Learning Model. https://www.rwlnetwork.org/rwl.aspx

Saldana, J. (2015). The coding manual for qualitative researchers. Sage.

Samperiz, A., \& Herrero, J. (2018). Evaluation of a summer camp environmental education program in Spain. Applied Environmental Education \& Communication, 17(1), 79-90.

Scott, W., \& Oulton, C. (2006). Environmental values education: An exploration of its role in the school curriculum. Journal of Moral Education, 27, 209-224.

Schwartz, S. H. (1994). Are there universal aspects in the structure and content of human values? Journal of Social Issues, 50, 19-45.

Sibthorp, J., Wilson, C., \& Browne, L. (2020). Active ingredients of learning at summer camp. Journal of Outdoor and Environmental Education, 23, 21-37.

Stern, M. J., Powell, R. B., \& Ardoin, N. M. (2008). What difference does it make? Assessing outcomes from participation in a residential environmental education program. The Journal of Environmental Education, 39(4), 31-43.

Stern, M. J., Powell, R. B., \& Hill, D. (2014). Environmental education program evaluation in the new millennium: What do we measure and what have we learned? Environmental Education Research, 20(5), 581-611.

Sutrop, M. (2015). Can values be taught? The myth of value-free education. Trames, 19, 189-202.

Talebpour, L. M., Busk, P. L., Heimlich, J. E., \& Ardoin, N. M. (2020). Children's connection to nature as fostered through residential environmental education programs: Key variables explored through surveys and field journals. Environmental Education Research, 26(1), 95-114.

Van Matre, S. (1990). Earth education: A new beginning. Institute for Earth Education.

West, S. E. (2015). Understanding participant and practitioner outcomes of environmental education. Environmental Education Research, 21(1), 45-60.

\section{Autoři}

PhDr. Roman Kroufek, Ph.D., Univerzita J. E. Purkyně, Pedagogická fakulta, Katedra preprimárního a primárního vzdělávání, Pasteurova 1, 40096 Ústí nad Labem, e-mail: roman.kroufek@ujep.cz

doc. PhDr. Jan Činčera, Ph.D., Masarykova univerzita, Fakulta sociálních studií, Katedra environmentálních studií, Joštova 10, 60200 Brno, e-mail: honzacincera@gmail.com 


\title{
Real-world learning: Experience with testing of an outdoor environmental education model
}

\begin{abstract}
The aim of the study is to present the main results of a three-year verification process of the Real World Learning model, designed for the preparation and implementation of outdoor environmental education programs. The research, carried out on five residential programs, involved lecturers and leaders of environmental education centers, accompanying teachers and pupils in the third to seventh grades of elementary school. Using qualitative (interview, focus groups, observation) and quantitative (questionnaire) research methods, the following variables related to the Real World Learning model were monitored: experiential learning, values, empowerment, program clarity, and the satisfaction with program. During the implementation of the programs, the lecturers tend to have a value-oriented influence on the participants, often focused on strong transformative experiences in nature. These experiences are positively received by the participants, pupils in the programs appreciate the elements of experiential learning and at the same time do not desire too much autonomy to influence the content and course of the program. The instrumental approach is also preferred by lecturers, supported in this view by accompanying teachers. These teachers perceive the programs primarily as an opportunity to develop the social competencies of their students. Recommendations for the implementation of outdoor environmental education programs are drawn from the presented results.
\end{abstract}

Keywords: outdoor environmental education, experiential learning, values, empowerment 